\title{
UNIWERSYTET Trzeciego WiEKu JAKO INSTYTUCJA PRZECIWDZIAŁAJACA MARGINALIZACJI OSÓB STARSZYCH
}

\author{
AleKSANDra MarcinKIEWicz \\ al.marcinkiewicz@gmail.com
}

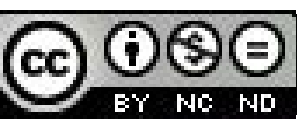

Postępujący proces starzenia się społeczeństwa sprawił, że zagadnienia dotyczące starości stały się jednym z głównych obszarów zainteresowań badaczy. Ważną rolę w przygotowaniu ludzi do starości przypisuje się Uniwersytetowi Trzeciego Wieku, który określany jest koroną edukacji całożyciowej. Jest to instytucja skierowana do osób starszych, której celem jest optymalizacja ich warunków życia oraz tworzenie możliwości wszechstronnego rozwoju¹.

Początków powstania instytucji należy szukać w dziewiętnastowiecznej Danii w koncepcji Uniwersytetu Ludowego stworzonego przez Nicolaia Fredrika Severina Grundtviga, który to zapoczątkował nurt kształcenia wszechnicowego². Pierwsza placówka tego typu skierowana do osób starszych, a mianowicie Uniwersytet Trzeciego Wieku (UTW) powstała we Francji w 1973 roku z inicjatywy profesora prawa międzynarodowego i socjologii Pierre'a Vellas. Należy zwrócić uwagę, że powstanie UTW poprzedzone było utworzeniem licznych organizacji działających na rzecz seniorów o zasięgu międzynarodowym ${ }^{3}$ i lokalnym. Świadczy to o rosnącym zainteresowaniu starością i problemami, które z niej wynikają. Pośrednim czynnikiem sprzyjającym powołaniu idyllicznej koncepcji P. Vellasa, był ruch młodzieży, domagającej się w 1968 roku reform uczelni. Splot powyższych wydarzeń zapoczątkował dynamiczny rozwój Uniwersytetów Trzeciego Wieku. Zakładano bowiem, że instytucje, oprócz stworzenia warunków wszechstronnego rozwoju seniorów, rozwiążą także problemy pośrednie. Mianowicie oczekiwano, że wprowadzenie starszego pokolenia na uczelnie osłabi buntownicze nastroje młodzieży oraz zapewni zatrudnienie kadrze profesorskiej, której liczba była wyższa, niż potrzeby uczelni ${ }^{4}$.

Klasyczny model funkcjonowania Uniwersytetu Trzeciego Wieku zakłada, że jest to instytucja uniwersytecka o charakterze gerontologicznym, więc jej powinnością są badania naukowe, które oscylują wokół problematyki starości i starzenia się, przyczyniając się do optymalizacji życia seniorów. Przy czym, celem nie jest jedynie poprawa warunków życia osób będących w późnej dorosłości, ale przede wszystkim pomoc w ich wszechstronnemu rozwoju. Uniwersytety Trzeciego Wieku są

1 O. Czerniawska, Uniwersytet Trzeciego Wieku, 30 lata działania. Przemiany, dylematy i oczekiwania w epoce ponowoczesnej, „„Chowanna”, t. 2, 2009, s.98.

2 J. Półturzycki, Uniwersytet powszechny, „Edukacja Dorosłych”, 1994, nr 3, s.19.

Do najistotniejszych organizacji działających na rzecz osób starszych, które poprzedziły powołanie UTW należą: Międzynarodowe Towarzystwo Gerontologiczne (IAG - International Association of Gerontology), Związek Organizacji Starszej Generacji Europy (EURAG - Fédération Européenne pour les Personnes âgées), Międzynarodowe Centrum Gerontologii Społecznej (CIGS - Centre International de Gérontologie Sociale) oraz Europejskiego centrum Badań i Zastosowań Opieki Społecznej (ECSWTR - European Centres fpr Social Welfare Training of Researche). W efekcie przedstawiciele powyższych organizacji powołali w 1980 roku Międzynarodową Federację Towarzystw Zrzeszających Osoby Starsze (FIAPA - Fédératiom Internationale des Associations des Personnes Âgées), która była afiliowaną przez ONZ i Radę Europy [R. Konieczna- Woźniak, 2001, s. 39-40]. Inną znaczącą organizacją działającą na rzecz osób starszych jest European Federation of Older Students (EFOS), która powstała w 1990 r. Działania EFOS koncentrują się na wspieraniu badań akademickich osób starszych w ramach UTW, promowanie wspólnych projektów UTW z całej Europy oraz wspieraniai zapewnienia dostępu osób starszych do akademickiejedukacji, także bez formalnych kwalifikacji. [ http://www.efos-europa.eu/history/, dostępne 15.11.2011]

4 R. Konieczna - Woźniak, Uniwersytety Trzeciego Wieku w Polsce. Profilaktyczne aspekty edukacji seniorów, Poznań 2001, s. 39-40. Zobacz także: O. Czerniawska, Uniwersytet Trzeciego Wieku, 30 lata...dz.cyt., s.98. 
częścią koncepcji kształcenia ustawicznego, zatem powinny szerzyć oświatę zdrowotna, pobudzać aktywność intelektualna, fizycznąi ekspresję artystyczna, jak i działaćna rzecz środowiska lokalnego ${ }^{5}$.

Doświadczenia różnorodnych form edukacji seniorów podejmowane w II poł XX wieku, odmienne systemy szkolnictwa w poszczególnych krajach, jak i różne warunki rozwoju społeczeństw spowodowały, że idea, struktura, jak i zakres działalności UTW z biegiem czasu ulegały zmianom ${ }^{6}$. Oprócz modelu klasycznego opisanego powyżej pojawily się także inne.

Jerzy Halicki?, poza modelem francuskim wyszczególnił jeszcze inne modele. Brytyjski model został opracowany przez Paula Laslett i zakłada charakter samopomocowy UTW, co przejawia się brakiem podziału na studentów i nauczycieli, jak i organizowaniem zajęć przez samych studentów. Rola uniwersytetu polega na stworzeniu metod pracy z osobami starszymi, a także zorganizowaniu sieci uniwersytetów z centralą nadzorującą ich funkcjonowanie.

Czym był dla Europy Uniwersytet Trzeciego Wieku, tym w Stanach Zjednoczonych stał się elderhoste. Koncepcja ta zakłada kształcenie osób starszych na wysokim poziomie połączone z podróżowaniem i przygodą (turnusy szkoleniowe - kilka dni zajęć dydaktycznych i wycieczka). Istotnym założeniem tej idei było ukazanie ludziom starszym nowych możliwości sensownego i twórczego życia we wspólnocie ${ }^{8}$.

Olga Czerniawska poza powyższych modelami pośrednimi wyróżnia także wariant internetowy obowiązujący w Australii, umożliwiający imigrantom naukę języka macierzystego, oraz model parazawodowych kompetencji obowiązujący w Chinach. Jego zadaniem jest pielegnacja kultury i obyczajów ważnych dla starszych Chińczyków, którzy po rewolucji kulturalnej stali się jedynym pokoleniem mogącym przekazać utracone dziedzictwo starożytnej kultury. Na chińskich Uniwersytetach Trzeciego Wieku oprócz języków obcych, informatyki, czy języka migowego, uczy się także kaligrafii, malowania, tańca, wycinania z papierów, podstaw medycyny naturalnej itp. ${ }^{9}$

Powstawanie pośrednich modeli Uniwersytetu Trzeciego Wieku ukazuje potrzeby, jak i możliwości społeczeństw je tworzących. Nowe tendencje w pracy UTW ujawniają się także w specyfice i tematyce prowadzonych badaniach. Pierwszym trendem wskazanym przez O. Czerniawską była integralność. Jednym z działan o tej tematyce był projekt realizowany na Uniwersytecie w Namur w Belgii w 2004 roku, który polegał na współpracy osób starszych z dziećmi przy tworzeniu encyklopedii przysłów. Zadaniem seniorów było zebranie przysłów będących symbolem mądrości społeczeństwa. Natomiast dzieci, z uwagi na sprawne posługiwanie się technikami informatycznymi przetworzyły i zarejestrowały na płycie $\mathrm{CD}$ zebrane przez starsze pokolenie przysłowia umożliwiając ich przekaz w społeczeństwie informacyjnym ${ }^{10}$.

Nowe technologie w nauce jak i przekazie międzypokoleniowym i międzykulturowym to następny ważny nurt $w$ pracy UTW. Przykładem projektu badawczego opartego na internecie jest stworzony w 1995 roku Ośrodek w Ulm „European Network in Later Life”, który prowadzi za pośrednictwem sieci kształcenie na poziomie wyższym. Przejawem podobnych dążeń są także badania zarówno międzygeneracyjne, jak i w obrębie jednej generacji prowadzone za pośrednictwem internetu, jak projekt „Świadkowie czasu” zrealizowany w 1999. Polegał on na spotkaniach młodzieży z seniorami w przestrzeni internetowej, gdzie dyskutowano na temat historii Niemiec ${ }^{11}$.

5 O. Czerniawska, Szkice z andragogiki i gerontologii, Łódź 2007, s. 216.

6 L. Schmidt, Uniwersytet Trzeciego Wieku w Polsce. Jedność w różnorodności (próba diagnozy), [w:] W. Wnuk (red.), Ludzie starsi w trzecim tysiacleciu: szanse, nadzieje, potrzeby, Wrocław 2002, s.132.

7 J. Halicki, Edukacja seniorów waspekcie teorii kompetencji. Studium historyczno - porównawcze, Białystok 2000, s. 42-51.

Tamże.

9 O.Czerniawska, Uniwersytet Trzeciego Wieku, 30 lata...dz.cyt., s. 99-100

O. Czerniawska, Szkice z andragogiki ...,dz.cyt. s. 223.

11 Tamże, s. 224-226. 
Kolejną tendencją, która uwidacznia się w Uniwersytetach Trzeciego Wieku jest wolontariat, który nawiązuje do modelu brytyjskiego. Oprócz zajęć i kursów prowadzonych w dużych grupach przez profesjonalistów powstają w ramach UTW koła studyjne. Są to małe grupy, które prowadzą wolontariusze, dzielący się swoją wiedzą i doświadczeniem. Inną formą wolontariatu słuchaczy UTW jest zaangażowanie w pomoc na rzecz generacji, ludzi z niepełnosprawnościa, osamotnionych, dzieci itp. ${ }^{12}$

Interesującym terminem pojawiającym się w literaturze jest „,czwarta generacja”, która charakteryzuje seniorów będących w najpóźniejszym okresie starości, czyli osoby powyżej osiemdziesiątego roku życia. W związku z czym pojawiają się zamysły powołania Uniwersytetu Czwartego Wieku, który skierowany ma być do tej grupy słuchaczy. Dokonano zatem podziału seniorów na osoby młodszo-starsze i starsze-sędziwe. Uniwersytet skierowany do grupy osiemdziesięciolatków w założeniu ma być uniwersytetem internetowym, domowym, umożlwiający edukację i uczestnictwo społeczne tej grupie osób, które nie sa już w stanie wyjsśc $\mathrm{z}$ domu ${ }^{13}$. $Z$ dużym prawdopodobieństwem będzie to kolejny obszar aktywności Uniwersytetu Trzeciego (Czwartego) Wieku.

Pojawiające się „"trendy" w działalności Uniwersytetów ściśle związane są z tematyką konferencji organizowanych przez Międzynarodowe Stowarzyszenie Uniwersytetów Trzeciego Wieku (AIU$\mathrm{TA})^{14}$. I tak na przykład, na XI kongresie AIUTA poszukiwano międzypokoleniowych związków uczenia się i przekazywania wzorców zachowań, wiedzy i umiejętności. O. Czerniawska to wydarzenie utożsamia z pojawieniem się nowej tendencji badań, których obszarem jest integralność. Natomiast zapoczątkowana tendencja dotycząca internetu poprzedzona była między innymi kongresem w Quebec, na którym zastosowano nowe technologie. Profesor J. Rosnay za pośrednictwem wideokonferencji wygłosił referat pt. „Interaktywność i interkreatywność w cybernetycznym przekazie XX wieku”. Z internetu korzystano również w przygotowaniu przebiegu kongresu w Chinach w 2004 roku. Innym przykładem ukazującym wpływ stowarzyszenia na rozwój UTW jest XXIII Kongres, który odbył się w 2006, w czasie którego poruszono kwestie Uniwersytetu Czwartego Wieku' ${ }^{15}$. Stuszne jest zatem stwierdzenie, że kongresy prowokują do rozważań nad kwestiami wcześniej nieporuszanymi, które w następstwie w zasadniczy sposób wpływają na kierunki rozwoju Uniwersytetów.

Nowe tendencje w UTW są nie tylko wyrazem nowych zainteresowań badawczych, ale również wskazują na problemy i potrzeby osób starszych. Podobnie jak powstanie nowych pośrednich modeli UTW, ukazują co w danym czasie jest szczególnie ważne dla członków uniwersytetu. Wspomniane trendy wynikają z potrzeb seniorów, a zatem są próbą wskazania dróg do ich zaspokojenia.

Nie da się zaprzeczyć, że specyficzne potrzeby seniorów wynikają z ich postępującego wieku. Starość często określana jest jako proces, w czasie którego następuje pogorszenie się sytuacji życiowej jednostki. Takie założenie zgodne jest $\mathrm{z}$ teorią stratyfikacji według wieku, $\mathrm{w}$ której wiek jest głównym czynnikiem określającym dostęp człowieka do powszechnie pożądanych dóbr. Zatem wraz ze starzeniem się jednostki zmniejsza się możliwość dostępu do tych obszarów. Wskazuje to na nierówną

12 Tamże, s. 228.

13 O. Czerniawska, Uniwersytet Trzeciego Wieku, 30 lat...dz.cyt, s. 106.

14 Association Internationale des Universités du Troisième Âge powstało w 1975 roku w celu zapewnia koordynacji i współpracy rozrastającej się sieci UTW. Pierwszym przewodniczącym został Pierre Vellas. Na początki istnienia organizacja skoncentrowała się na szerzeniu idei UTW wśród jednostek akademickich. Główny cel działalności skupiał się na zapewnieniu współpracy między UTW na świecie oraz podobnymi instytucjami dla seniorów proponujących kształcenie na poziomie uniwersyteckim, jak i z instytucjami gerontologicznymi. Obecnie stowarzyszenie AIUTA wydaje listy informacyjne i łącznościowe dla wszystkich stowarzyszonych członków, organizuje kongresy, seminaria, warsztaty, wymianę kadry naukowej i uczestników. AIUTA jest uznawana za eksperta w zakresie gerontologii przez takie organizacje międzynarodowe jak: UNESCO, ONZ, Światowa Organizacja Zdrowia, Radę Europy.

15 O. Czeriawska, Szkice z andragogiki....dz.cyt., s. 223-229. 
redystrybucję dóbr społecznie pożądanych. Osoby będące w późnej dorosłości tracą swoją pozycję społeczną na skutek zaprzestania aktywności zawodowej, zmniejszenia się wielkości dochodów, zawężenia się sieci kontaktów nieformalnych ${ }^{16}$. Taki stan rzeczy zwiększa prawdopodobieństwo marginalizacji, a nawet wykluczenia społecznego osób starszych.

Pojęcie marginalizacji, jak i wykluczenia społecznego nie jest jednoznaczne i może być w różny sposób definiowane. M. Parchomiuk uważa, że wykluczenie społeczne, czyli ekskluzja jest bardziej zaawansowaną formą marginalizacji. Zjawisko to można ujmować jako proces, czyli dynamicznie lub jako sytuację, a więc statycznie. Zatem marginalizacja to proces pełnego odcięcia lub częściowego ograniczenia dostępu do rozmaitych systemów (społecznych, gospodarczych, kulturowych i politycznych), które pomagają osobie w integracji społecznej. Wykluczenie można również traktować jako szeroki zakres deprywacji uniemożliwiający jednostkom, czy też grupom pełne uczestnictwo w życiu społecznym, jak i korzystanie z publicznych i prywatnych usług, czego rezultatem jest fakt, że jednostki i społeczeństwo przez nie tworzone stają się nierówne, społecznie zróżnicowane i spolaryzowane ${ }^{17}$.

Komisja Unii Europejskiej za wykluczenie społeczne uznaje proces, którego skutkiem jest zepchnięcie na margines społeczeństwa pewnych jednostek, które ze względu na brak podstawowych kwalifikacji i możliwości uczestnictwa w kształceniu nie są dopuszczane do pełnego uczestnictwa w życiu społecznym. Osoby zmarginalizowane mają również ograniczony dostęp do decyzyjnych ośrodków władzy, przez co odczuwają bezsilność i brak możliwości wpływu na decyzje, które bezpośrednio oddziaływają na ich życie ${ }^{18}$. Zatem można mówić o wykluczeniu:

- $\quad$ społecznym o charakterze strukturalnym - związanym z miejscem zamieszkania, niskim wykształceniem;

- fizycznym - związanym z niepełnosprawnością lub wiekiem;

- normatywnym -związanym z samotnościa, konfliktami z prawem czy uzależnieniem ${ }^{19}$.

W związku z faktem, iż powyższe rozważania dotyczą osób starszych, wykluczenie społeczne o charakterze strukturalnym, które związane jest z niskim wykształceniem, będzie określane jako wykluczenie intelektualne, wykluczenie fizyczne jako biologiczne, natomiast normatywne, jako psychofizyczne.

Reasumując, wykluczenie społeczne w większości definicji określane jest jako niemożność uczestniczenia $\mathrm{w}$ istotnych obszarach życia społecznego, gospodarczego, kulturalnego, czy politycznego. Przy czym, brak uczestnictwa we wspomnianych obszarach nie wynika z wyboru jednostki, lecz przeszkód jakie ona napotyka ${ }^{20}$.

Analizując działania UTW mające na celu przeciwdziałanie marginalizacji należy uwzględnić te, które bezpośrednio oddziaływają na seniora oraz te, które wywierają wpływ na społeczeństwo. Taki sposób spojrzenia można uzasadnić tym, że przede wszystkim UTW powinno oddziaływać na osoby starsze, $\mathrm{w}$ taki sposób, aby zwiększać ich możliwości przezwyciężenia barier uniemożliwiających im uczestnictwo w społeczeństwie. Natomiast, oddziaływania na społeczeństwo powinny doprowadzić

16 Z, Szweda- Lewandowska, Zapotrzebowanie na instytucjonalne formy pomocy osobom starszym w perspektywie dwudziestu pięciu lat w świetle aktualnych determinant w mikro- i makroskali.[w:] J. Kowalewski (red.), Przestrzenne zróżnicowanie starzenia się ludności Polskiej. Przyczyny, etapy, następstwa, Łódź 2011, s. 169-179.

17 M. Parchomiuk, Niepełnosprawni- społecznie wykluczeni?, „Niepełnosprawność i Rehabilitacja”, nr 4, 2006, s. 4.

18 S. Golinowska, P. Broda-Wysocki, Kategoria ubóstwa i wykkluczenia społecznego. Przegląd ujęć, [w:] S. Golinowska, E. Tarkowska, I. Topińska (red.), Ubóstwo i wykluczenie społeczne. Badania. Metody. Wyniki, Warszawa 2005, s. 47.

19 M. Rek, W. Woźniak, Wyrównywanie szans? Reforma polskiego systemu edukacji a realizacja idei inkluzji społecznej, [w:] J. Grotowska-Leder, K. Faliszek (red.), Ekskluzja i inkluzja społeczna. Diagnoza- uwarunkowania-kierunki działań, Toruń 2005, s. 141.

20 T. Panek, Ubóstwo, wykluczenie społeczne i nierówności. Teoria i praktyka pomiaru, Warszawa 2011, s.16. 
do pełnego zaakceptowania tej grupy osób przez zmianę wizerunku osoby starszej, jak i zwrócenie uwagi na ich problemy.

Badania na temat działań UTW dotyczące przeciwdziałania marginalizacji osób starszych prowadziła Beata Ziębińska. Autorka rolę uniwersytetu w przeciwdziałaniu wykluczeniu seniorów upatruje przede wszystkim w różnego rodzaju formach ich aktywizacji, do których zaliczyła aktywizację społeczna, fizyczną oraz intelektualną. B. Ziębińska skupia się przede wszystkim na działaniach UTW skierowanych na jednostkę, które mają wykształcić umiejętność radzenia sobie z przeszkodami uniemożliwiającymi pełne uczestnictwo społeczne. Zbliżone badania prowadziła także Renata Konieczna - Woźniak ${ }^{21}$, która skupiła się przede wszystkim na profilaktycznym aspekcie edukacji seniorów. W obu przypadkach badaniom poddano te same obszary aktywizacji studentów przez UTW, co zapewne wynika z definicji Uniwersytetu Trzeciego Wieku.

Aktywizacja społeczna słuchaczy UTW odbywa się między innymi poprzez działalność sekcji lub zespołów pomocy koleżeńskiej. Celem ich funkcjonowania jest utrzymanie więzi z byłymi studentami UTW, które ze względów zdrowotnych nie mogą już uczestniczyć w zajęciach. Działalność ich polega na udzielania wsparcia psychicznego, jak i materialnego w sytuacjach kryzysowych. Można zatem wysunąc wniosek, że uczestnictwo w UTW pozwala rozwinać sieć kontaktów nieformalnych, na które jednostka może liczyć w sytuacjach trudnych. Aktywność społeczna seniorów wyraża się również przez pracę w samorządzie uniwersytetu. Członkowie samorządu zajmują się przede wszystkim zadaniami statutowymi, ale i realizują inne czynności wynikające z organizacji różnego rodzaju imprez okolicznościowych. Coraz częściej praktykowaną formą aktywności jest działalność seniorów na rzecz środowiska lokalnego, często we współpracy z innymi organizacjami. Charakter tych działań wynika ze specyfiki środowiska lokalnego, zatem trudne jest wskazanie na konkretne obszary oddziaływań. Uniwersytet Trzeciego Wieku jest również miejscem, które umożliwia realizację nowych ról społecznych, takich jak wolontariat. Dzięki uczestnictwu w uniwersytecie prawie co dziesiąty słuchacz został wolontariuszem. Jednak badania ukazuja, że UTW aktywizuje seniorów przede wszystkim w ramach własnych działań, takich jak praca w samorządzie, udział w sekcjach koleżeńskich, uczestnictwo w rozmaitych akcjach organizowanych przez UTW, przede wszystkim w środowisku lokalnym. Uniwersytety Trzeciego Wieku raczej nie pomagają w poszukiwaniu nowych ról w innych organizacjach $^{22}$.

Podobne wyniki badań w zakresie aktywizacji społecznej uzyskała R. Konieczna- Woźniak, przy czym były one rozszerzone o kwestie upowszechnianie idei Uniwersytetu Trzeciego Wieku w najbliższym środowisku. Z jej badań wynika, że 74\% słuchaczek i 64 \% słuchaczy deklarowało, że wprowadzili do UTW nowych uczestników - często byli to członkowie ich rodzin. Autorka zwróciła uwagę także na inne zjawisko, charakterystyczne dla UTW, a mianowicie nawiązywanie nowych kontaktów towarzyskich przez seniorów. Ponad 90\% seniorów przyznało, że uczestnictwo w zajęciach UTW umożliwiło im nawiązanie nowych relacji towarzyskich ${ }^{23}$. Ten aspekt jest istotny w odniesieniu do wspomnianych już sieci kontaktów.

Profilaktyka gerontologiczna rozumiana jest jako szeroki zakres oddziaływań mających przeciwdziałać negatywnym skutkom starzenia się człowieka. Jednym zjej aspektów jest aktywizacja intelektualna seniorów. W Uniwersytecie Trzeciego Wieku aktywizacja ta odbywa się przez wykłady, sekcje, seminaria i koła zainteresowań oraz rozmaite kursy. Podstawową formą działalności w tym obsza-

\footnotetext{
${ }^{21}$ R. Konieczna- Woźniak, dz.cyt, s. 98-102.

22 B. Ziębińska, Uniwersytet Trzeciego Wieku jako instytucje przeciwdziałające marginalizacji osób starszych, Katowice 2010, s. 259-267.

${ }^{23}$ R. Konieczna- Woźniak,dz.cyt., s.94-100.
} 
rze są wykłady, przeważnie o tematyce dotyczącej ochrony zdrowia i medycyny związanej z chorobami wieku starszego. Jest to najpopularniejsza forma aktywności, gdyż 94,1\% badanych uznało ją za najchętniej uczęszczaną formą zajęć w UTW. Wysoki wyniki dotyczącej tej kwestii otrzymała w swoich badaniach R. Konieczna-Woźniak - 86\% uznało wykłady za ulubione zajęcia. Sekcje, seminaria i koła zainteresowań służą pogłębianiu wiedzy z danego obszaru, często wzbogacone są własną twórczościa, która to w wieku późnej dorosłości jest sposobem dalszego rozwoju jednostki. Proces twórczy umożliwia postrzeganie rzeczywistości mniej fragmentarycznie. Sprzężony jest on ściśle z proces poznawania (uczenia się). Z przeprowadzonych przez B. Ziębińską badań wynika, że do zajęć najbardziej rozbudzających proces twórczy należą: sekcje, zespoły, koła literackie, żywego słowa, muzyczne, plastyczne, malarskie, warsztaty samorealizacji, sceniczne, rękodzieła artystycznego, ogrodniczo-kwiaciarskie, kronikarskie, redakcyjne, robót ręcznych i fotograficzne. UTW umożliwia również rozwijanie kompetencji niezbędnych w społeczeństwie informacyjnym, takich jak obsługa komputera, korzystanie z internetu czy naukę języków obcych. Z czterdziestu pięciu badanych przez nią uniwersytetów tylko pięć nie prowadziło takich zajęć. Największa liczba osób korzystała z lektoratów języka obcego - 26,2\% seniorów wskazało, że to jest najchętniej uczęszczana przez nich forma zajęć. Ponadto, $83 \%$ respondentów uznało znajomość języka obcego za przydatną $2^{24}$. Podobne wyniki uzyskała R. Konieczna-Ziębińska.

Uniwersytety Trzeciego Wieku starają się przełamać nieufność osób starszych wobec nowych technologii. Termin e-inkluzja (e-Inclusion) $)^{25}$ oznacza działania mające na celu przeciwdziałanie analfabetyzmowi cyfrowemu oraz włączenie najstarszych obywateli Europy w społeczność digitariatu. W związku z powyższym oferta UTW zawiera m. in.: kursy obsługi komputera, poruszania się w sieci, korzystania z poczty elektronicznej. Zajęcia te mają na celu oswajanie uczestników z technologiami teleinformatycznymi. Skupiają się na wykorzystywaniu ich dla potrzeb funkcjonowania seniorów w życiu codziennym ${ }^{26}$. Przy czym, zajęcia komputerowe w poszczególnych UTW spotykają się z różnym odbiorem ze strony uczestników. Niemniej, z badań wynika, że słuchacze generalnie uważają kompetencje związane z obsługą urządzeń informatycznych za istotne. Seniorzy za użyteczne uznali umiejętności korzystania z komputera $(74 \%)$ oraz internetu (71\%). Jak zwraca uwagę autorka, istotność umiejętności niezbędnych $\mathrm{w}$ społeczeństwie informacyjnych dostrzegają przede wszystkim osoby z najmłodszej kategorii wiekowej, posiadające wyższe wykształcenie, mieszkające z dziećmi ${ }^{27}$.

R. Konieczna-Woźniak w badaniach podjęła również kwestie kształcenia ustawicznego oraz badań naukowych prowadzonych przez UTW, które również można uznać za formę aktywność intelektualną. Pozwalają one wnioskować, że edukacyjne zainteresowania seniorów w dużej mierze są rezultatem ich wcześniejszych doświadczeń edukacyjnych. Generalnie Uniwersytety Trzeciego Wieku zaspokajają potrzeby poznawcze uczestników (w stopniu: wysokim $36 \%$, bardzo wysokim $27 \%$, średnim 29\%, małym 5\%, żadnym 1\%). Według autorki taki rozkład odpowiedzi można uzasadnić tym, że część słuchaczy zaangażowana jest równocześnie w edukację poza uniwersytetem i w ten sposób uzupełnia swoje potrzeby edukacyjne. Wyniki wskazuja, że na zaspokojenie potrzeb poznawczych mają wpływ, choćnie decydujący, takie czynniki jak: płeć, poziom wykształcenia i czas przynależności do UTW ${ }^{28}$.

24 Tamże, 267-276.

25 Z. Szarota, Przestrzeń edukacyjna Uniwersytetu Trzeciego Wieku, dostępne w Internecie: http://www.e-mentor.edu. pl/artykul/index/numer/25/id/559, dane z dnia: 12.04.2011, internetowe wydanie czasopisma ,e-mentor", nr 3, 2008.

26 Tamże.

27 B. Ziębińska, dz.cyt, s. 274-276.

28 R. Konieczna-Woźniak ,dz.cyt., s.107-113.

Ogrody NAUK I SZTUK NR 2012 (2) 
Istotny aspektem w kwestii pobudzania intelektualnego seniorów jest działalność naukowo-badawcza UTW. Kwestię tę można rozpatrywać trójaspektowo: jako prowadzenie badań naukowych przez samych słuchaczy, jako zaangażowanie słuchaczy w badania prowadzone przez kadrę naukową dotyczące profilaktyki gerontologicznej; jako upowszechnianie wyników badań z obszaru gerontologii w UTW i poza. Z badań wynika, że dominuje druga forma zaangażowania, czyli słuchacze biorą udział w badaniach prowadzonych przez naukowców. Niemniej, w uniwersytecie prowadzone są także badania przez samych uczestników w ramach seminariów - 9\% deklarowało bezpośrednie zaangażowanie w badania. Można zatem wysunąć postulat rozszerzenia profilu naukowego UTW angażując większą liczbę seniorów $\mathrm{w}$ badania naukowe, $\mathrm{z}$ naciskiem na samodzielne ich prowadzenie. Jest to istotne pole działalności UTW, które świadczy o randze i naukowym autorytecie instytucji ${ }^{29}$.

Działania profilaktyczne zalecają wczesne rozpoczęcie aktywności ruchowej, która u osób starszych wpływa korzystnie na ogólne samopoczucie, poprawia zdrowie fizyczne i psychiczne, jak i wspomaga prewencję określonych stanów i chorób. Inną korzyścią wynikającą z aktywności fizycznej jest zmiana stereotypu człowieka starszego, jako niedołężnego oraz zachowanie niezależnego trybu życia ${ }^{30}$. Z badań B. Ziębińskiej wynika, że najczęściej proponowaną formą zajęć ruchowych jest różnego rodzaju gimnastyka i turystyka. Seniorzy są osobami aktywnymi ruchowo - $87 \%$ z nich uprawia jakiś rodzaj aktywności ruchowej, przy czym 71\% badanych uprawia aktywność w ramach uczestnictwa w UTW. 72\% seniorów przyznało, że aktywność fizyczna zdecydowanie poprawia ich samopoczucie, $24 \%$ stwierdziło, że raczej poprawia, a 3\% badanych stwierdziło, że nie wie czy ruch wpływa na ich samopoczucie ${ }^{31}$. Jednak, prawie $30 \%$ respondentów nie korzysta z zajęć ruchowych proponowanych przez Uniwersytet. Wyniki badań świadczą o korzystnym wpływie ćwiczeń na życie seniorów, zatem aktywizacja w tym obszarze wydaje się być istotna z punktu widzenia działalności $\mathrm{UTW}^{32}$.

Jednoczesna aktywizacja seniorów w powyższych obszarach wydaje się być tym istotniejsza, gdyż tylko w ten sposób można kompleksowo oddziaływać na jednostkę, maksymalnie zwiększając jej umiejętności i możliwości radzenia sobie z sytuacjami trudnymi. Poszczególne aktywności nie należy ujmować osobno, lecz całościowo, gdyż jedynie tak można przeciwdziałać marginalizacji wynikającej z różnych obszarów funkcjonowania jednostki.

Należy jeszcze raz podkreślić, że przeciwdziałanie marginalizacji nie obejmuje jedynie działań ukierunkowanych na jednostkę, ale także na społeczeństwo. Niepokojący jest fakt, że w przytoczonych badaniach kwestia odziaływań UTW na społeczeństwo nie została dostatecznie opracowana. B. Ziębińska w pewien sposób starała się w swojej pracy ująć ten aspekt, analizując zmiany zachodzące w relacji seniora z jego rodziną i najbliższym otoczeniem. Niemniej, badano jedynie seniorów, a więc wyniki dotyczące społeczeństwa opierały się na subiektywnej ocenie uczestników UTW, a nie wypły-

29 Tamże, 113-119.

30 G. Dąbrowska, A. Skrzek, Kultura fizyczna ludzi starych, [w:] W. Wnuk, Ludzie starzy w trzecim tysiacleciu. Szanse. Nadzieje. Potrzeby, Wrocław 2002,s. 35-37.

31 W badaniach R. Koniecznej-Woźniak poddano analizie subiektywną ocenę kondycji fizycznej przez seniorów. Ponad połowa badanych (51,5\%) oceniła swój stan zdrowia jako dobry, 41,9\% uznało go jako średni, a jedynie 4,2\% określiła go jako zły. Porównując te dane z wynikami Zbigniewa Woźniaka, który prowadził badania nad najstarszymi mieszkańcami Poznania, wyniki sprawności fizycznej uczestników UTW wypadają zaskakująco dobrze. W jego baniach respondenci swoją kondycję fizyczną ocenili jako dobrą w 34,4\%, dostateczną w 25,5\%, a jako złą 40,2\% (R. Konieczna-Woźmniak, dz. cyt., s. 100-102). Powyższe wyniki badań mogą mieć dwa wyjaśnienia. Po pierwsze, rozbieżność w subiektywnej ocenie stanu fizycznego przez seniorów może wynikać z tego, że do UTW uczęszczają przede wszystkim osoby sprawne lub z niewielkimi niepełnosprawnościami. Drugim wyjaśnieniem może być fakt, że lepsza ocena subiektywna członków UTW jest wynikiem aktywizacji ruchowej organizowanej w ramach Uniwersytetu.

32 B. Ziębińska, dz.cyt., s. 280-287. 
wały bezpośrednio od społeczeństwa (członków rodzin, sąsiadów itp.), a więc nie można ich uznać za reprezentatywne.

Odwołując się do przywołanych wcześniej obszarów wykluczenia (intelektualne, biologiczne i psychofizyczne) można ukazać, jak poszczególne działania Uniwersytetu Trzeciego Wieku przeciwdziałają temu negatywnemu zjawisku.

Tabela 1. Rola uniwersytetu Trzeciego Wieku w przeciwdziałaniu skutkom wykluczenia społecznego

\begin{tabular}{|c|c|c|c|}
\hline & \multicolumn{3}{|c|}{ OBSZARY WYKLUCZENIA SPOŁECZNEGO } \\
\hline & Wykluczenie intelektualnie & Wykluczenie biologiczne & $\begin{array}{l}\text { Wykluczenie } \\
\text { psychofizyczne }\end{array}$ \\
\hline $\begin{array}{l}\text { Działania } \\
\text { UTW }\end{array}$ & $\begin{array}{l}\text { AKTYWIZACJA } \\
\text { INTELEKTUALNA: } \\
\text {-zdobycie wykształcenia; } \\
\text {-Szacunek i prestiż } \\
\text { społeczny; } \\
\text {-Wykorzystanie twórczego } \\
\text { potencjału seniorów }\end{array}$ & $\begin{array}{l}\text { AKTYWIZACJA } \\
\text { RUCHOWA: } \\
\text {-zajęcia fizyczne; } \\
\text {-wycieczki; } \\
\text {-wykłady prozdrowotne }\end{array}$ & $\begin{array}{l}\text { AKTYWIZACJA } \\
\text { SPOEECZNA: } \\
\text {-wolontariat; } \\
\text {-poszerzanie sieci } \\
\text { kontaktów; } \\
\text {-UTW jako miejsce } \\
\text { zaspokojenia } \\
\text { indywidualnych potrzeb } \\
\text { (teoria kompensacji) } \\
\end{array}$ \\
\hline $\begin{array}{l}\text { Nowe } \\
\text { tendencje } \\
\text { w badaniach } \\
\text { i pracy UTW }\end{array}$ & Nowe technologie & $\begin{array}{l}\text { Uniwersytet Czwartego } \\
\text { Wieku }\end{array}$ & $\begin{array}{l}\text { Integralność } \\
\text { Wolontariat }\end{array}$ \\
\hline $\begin{array}{l}\text { Modele pracy } \\
\text { z seniorami }\end{array}$ & Model francuski & Model amerykański & Model brytyjski \\
\hline
\end{tabular}

Źródło: opracowanie własne.

Wykluczenie społeczne o charakterze strukturalnym związane jest między innymi z miejscem zamieszkania lub niskim wykształceniem. O ile na pierwszą ze zmiennych UTW nie mają bezpośredniego wpływu, to wykształcenie jest tym obszarem, gdzie ich rola jest znacząca. Uniwersytety Trzeciego Wieku są przede wszystkim miejscem rozwoju intelektualnego seniorów. Umożliwiają dostęp do kształcenia również tym jednostka, które we wcześniejszych etapach życia nie miały takiej okazji. Instytucja ta przez organizowane zajęć wyposaża uczestników w kompetencje niezbędne w nowej rzeczywistości informatycznej, jak i pozwala na wykorzystanie twórczego potencjału uczestników. Ponadto, fakt przynależności do instytucji uniwersyteckiej i rozszerzanie swoich zasobów intelektualnych jest źródłem gratyfikacji, w postaci szacunku i prestiżu społecznego. Potwierdzeniem działań przeciwdziałających wykluczeniu intelektualnym jest tendencja dotycząca rozwoju nowych technologii na uniwersytecie. Wszystkie modele UTW w swojej działalności oddziałują na wszystkie trzy formy aktywizacji, przy czym można zauważyć, że poszczególne modele kładą większy nacisk na 
określoną aktywizację, która niejako wynika z charakteru danego modelu. Francuski model UTW w swojej działalności akcentuje aspekt naukowy instytucji, w związku z czym mieści się w obszarze przeciwdziałania marginalizacji intelektualnej.

Przedsięwzięciem będącym odpowiedzią na marginalizację o charakterze biologicznym (wynikająca z niepełnosprawności lub wieku) jest przede wszystkim aktywizacja ruchowa osób starszych. Aktywności te mają na celu utrzymanie seniorów w możliwie najlepszej kondycji fizycznej, pozwalającej na pełną sprawność, co pozwala na odroczenie w czasie widma niepełnosprawności. Zainteresowanie UTW „czwartym wiekiem” odzwierciedla jego gotowość wsparcia również tych jednostek, których stan zdrowia nie pozwala na fizyczne uczestnictwo w zajęciach. Niesprawność fizyczna nie będzie już zatem determinantem warunkującym wykluczenie społeczne jednostki. Model amerykański pracy z seniorami, który charakteryzuje się podróżowaniem i aktywizacją seniorów przez przygodę pośrednio akcentuje również aspekt fizyczny starzenia się i zwraca uwagę na utrzymanie jak najlepszej kondycji przez uczestników oraz promuje zdrowy styl życia.

Wykluczenie psychofizyczne związane jest z doświadczaniem samotności, która jest często odczuwana przez osoby starsze. Działaniami uniwersytetu niwelującymi poczucie osamotnienia jest aktywizacja społeczna. Zaangażowanie w wolontariat, pracę na rzecz placówki lub społeczności pozwala rozwinąć sieć kontaktów nieformalnych, w postaci nowych relacji towarzyskich. Ponadto, zgodnie $\mathrm{z}$ teorią kompensacji Uniwersytet Trzeciego Wieku stanowi miejsce zaspokajania indywidualnych potrzeb seniorów. Tendencje w działalności UTW dotyczące integralności oraz wolontariatu również są dowodem na przeciwdziałanie marginalizacji wynikającej z poczucia osamotnienia. Należy zwrócić uwagę, że wolontariat, samopomoc oraz samokształcenie to cechy charakterystyczne dla modelu brytyjskiego.

Niezaprzeczalnie Uniwersytet Trzeciego Wieku znacząco wpływa na jakość życia swoich uczestników. Aktywizuje ich zarówno intelektualnie, społecznie i ruchowo wpływając na ich możliwości radzenia sobie w sytuacjach trudnych, a tym samym minimalizując niebezpieczeństwo marginalizacji społecznej. Niemniej jednak instytucje tego typu chcąc lepiej przeciwdziałać temu zjawisku muszą w większym stopniu oddziaływać na społeczeństwo, zmieniając wizerunek osoby starszej. Efekt ten można osiagnąć przez organizację konferencji, publikacje naukowe i popularnonaukowe, wolontariat, czy współpracę z środowiskiem lokalnym.

Należy także pamiętać, że do UTW uczęszczają przede wszystkim osoby sprawne fizyczne, posiadające średnie i wyższe wykształcenie, czyli elita intelektualna starszej generacji. Działania powinny skupić się na sposobach dotarcia do reszty polskich seniorów, gdyż tylko w ten sposób można mówić o rzeczywistym przeciwdziałaniu marginalizacji wśród osób starszych. Jednym z rozwiązań jest tworzenie Uniwersytetów Trzeciego Wieku w małych miejscowościach i na wsi, z zachowaniem możliwe wysokich standardów kształcenia.

Ważnym aspektem w działaniach UTW powinna być współpraca międzypokoleniowa. Nie chodzi tu jedynie o działania wynikające z realizacji projektów związanych z tym tematem, choć są one bardzo ważne, ale o naturalną kooperację pokoleń, która realizowana jest $\mathrm{w}$ ramach UTW. Taka partycypacja idei dialogu międzypokoleniowego, nie jako wydarzenia incydentalnego, ale stały element pracy uniwersytetu sprawi, że dialog międzygeneracyjny rzeczywiście będzie miał miejsce. Wpłynie to na zmianę wizerunku osób starszych, jak i młodzieży oraz nie dopuści do zamykania się seniorów we własnym gronie (automarginalizacji), dając tym samym możliwość jeszcze większego ich rozwoju. 


\section{Bibliografia}

Czerniawska O., Szkice z andragogiki i gerontologii, Łódź 2007.

Czerniawska O., Uniwersytet Trzeciego Wieku, 30 lata działania. Przemiany, dylematy i oczekiwania w epoce ponowoczesnej, „Chowanna" 2009, t. 2.

Dąbrowska G., Skrzek A., Kultura fizyczna ludzi starych, [w:] Wnuk W. (red.), Ludzie starzy w trzecim tysiacleciu: szanse, nadzieje, potrzeby, Wrocław 2002.

Golinowska S., Broda -Wysocki P., Kategoria ubóstwa i wykluczenia społecznego. Przegląd ujęć, [w:] Golinowska S. , Tarkowska E., Topińska I. (red.), Ubóstwo i wykluczenie społeczne. Badania. Metody, Wyniki, Warszawa 2005.

Golinowska S., Tarkowska E., Topińska I. (red.), Ubóstwo i wykluczenie społeczne. Badania. Metody. Wyniki, Warszawa 2005.

Grotowska-Leder J, Faliszek K. (red.), Ekskluzja i inkluzja społeczna. Diagnoza- uwarunkowania-kierunki działań, Toruń 2005.

Halicki J., Edukacja seniorów w aspekcie teorii kompetencji. Studium historyczno - poróznaweze, Białystok 2000.

Konieczna-Woźniak R., Uniwersytety Trzeciego Wieku w Polsce. Profilaktyczne aspekty edukacji seniorów, Poznań 2001.

Kowalewski J. (red.), Przestrzenne zróżnicowanie starzenia się ludności Polskiej. Przyczyny, etapy, następstwa, Łódź 2011.

Panek T., Ubóstwo, wykluczenie społeczne i nierówności. Teoria i praktyka pomiaru, Warszawa 2011.

Parchomiuk M., Niepełnosprawni- społecznie wykluczeni?, „Niepełnosprawność i Rehabilitacja” 2006, nr 4.

Półturzycki J., Uniwersytet powszechny, „Edukacja Dorosłych” 1994, nr 3.

Rek M., Woźniak W., Wyrówonywanie szans? Reforma polskiego systemu edukacji a realizacja idei inkluzji spotecznej, [w:] Grotowska-Leder J., Faliszek K. (red.), Ekskluzja i inkluzja społeczna. Diagnoza- uwarunkowania-kierunki działań, Toruń 2005

Schmidt L., Uniwersytet Trzeciego Wieku w Polsce. Jedność w różnorodności (próba diagnozy), [w:] Wnuk W. (red.), Ludzie starsi $w$ trzecim tysiacleciu: szanse, nadzieje, potrzeby, Wrocław 2002.

Szweda-Lewandowska Z., Zapotrzebowanie na instytucjonalne formy pomocy osobom starszym w perspektywie dwudziestu pieciu lat w świetle aktualnych determinant w mikro- i makroskali, [w:] Kowalewski J. (red.), Przestrzenne zróżnicowanie starzenia się ludności Polskiej. Przyczyny, etapy, następstwa, Łódź 2011.

Wnuk W. (red.), Ludzie starsi w trzecim tysiacleciu: szanse, nadzieje, potrzeby, Wrocław 2002.

Ziębińska B., Uniwersytety Trzeciego Wieku jako instytucje przeciwdziałające marginalizacji osób starszych, Katowice 2010.

\section{Netografia}

http://www.efos-europa.eu/history/, 15.11.2011.

Szarota Z., Przestrzeń edukacyjna Uniwersytetu Trzeciego Wieku, http://www.e-mentor.edu.pl/artykul/index/numer/25/ id/559, 12.04.2011, internetowe wydanie czasopisma „e-mentor" 2008, nr 3.

\section{STRESZCZenie}

Artykuł przedstawia rolę Uniwersytetu Trzeciego Wieku w przeciwdziałaniu skutkom marginalizacji osób znajdujących się w późnej dorosłości. Zaprezentowano także zarys historyczny UTW i dokonano charakterystyki poszczególnych modeli tej instytucji. Przedstawiono również tendencje pojawiające się w badaniach prowadzonych przez uczestników UTW i wykazano ich związek z działaniami prowadzonymi w kwestii włączenia ludzi starszych w nurt życia społecznego.

Słowa kluczowe: Uniwersytet Trzeciego Wieku, wykluczenie społeczne, marginalizacja, seniorzy, kształcenie ustawiczne

\section{University of the Third Age as an Institution Preventing Marginalization OF THE ELDERLY}

\section{Summary}

The article presents the role of the Third Age University in counteracting the effects of marginalization of the elderly. The history of the University of Third Age was presented and also different models of this institution was characterized. The paper presents new trends in research conducted by participants of UTA and shown their relation with marginalization.

Key words: University of Third Age, social exclusion, marginalization, seniors, Life Long Learning, 